\title{
Impact of external factors on humidity migration processes in walls made from autoclaved aerated concrete
}

\author{
M. Vilnītis ${ }^{1}$, J. Noviks ${ }^{1}$, B. Gaujēna ${ }^{1}$ \& J. Paplavskis ${ }^{2}$ \\ ${ }^{I}$ Riga Technical University, Institute of Building Production, \\ Latvia \\ ${ }^{2}$ AEROC International AS, Estonia
}

\begin{abstract}
The paper is devoted to the analysis of humidity migration and heat transfer processes in walls made from a new generation of autoclaved aerated concrete blocks. The paper gives experimental results of humidity migration and heat transfer processes in a new generation of autoclaved aerated concrete walls as well as measurements of climatic data during the experiment. Analyzing experimental data, the model for climatic data evaluation in the Baltic Sea states was created and tested. The influence of a new generation of autoclaved aerated concrete wall finishing materials on the drying process of the wall was also studied in this paper.
\end{abstract}

Keywords: autoclaved aerated concrete, climate modeling, humidity migration.

\section{Introduction}

With this publication we would like to share experimental and theoretical studies on a new generation of autoclaved aerated concrete wall moisture migration modelling in relation to conditions and external finishes' effects. The term of new generation of autoclaved aerated concrete in our publication, is understood as autoclaved aerated concrete blocks with volume weights from 300 to $400 \mathrm{~kg} / \mathrm{m}^{3}$, a dimensional accuracy of $+/-1 \mathrm{~mm}$ and forming joints in wall with glue mortar. In the European Union, former USS Republics and the Baltic states various research, technological and practical activities have taken place [2-5] dedicated to the decision of the heat-engineering problem of walling and 
materials. There are made many different experiments $[1,4,7]$ that give grounds for the theoretical and practical basis of various heat-engineering issues. Autoclaved aerated concrete manufacturers and construction companies who actively investigate home and foreign experience, and introduce it in construction practice nowadays make a substantial contribution to the research of autoclaved aerated concrete qualities.

Considering the information mentioned above, the investigation of the moisture migration processes and their modeling opportunities associated with various external impacts and heat flow processes in autoclaved aerated concrete exterior wall containment structures is essential. This publication studies the possibility of weather modeling and describes the thermal processes of interdependence and impact issues. In conclusion, the analysis of moisture migration processes in a new generation of autoclaved aerated concrete external walls with a volume weight from 350 to $400 \mathrm{~kg} / \mathrm{m}^{3}$ is made and both external and internal climatic factors and the effects of finishing materials in this process are specified.

\section{The results of experiments}

This experiment was carried out in Tallinn Technical University [1], where a pilothouse with embrasures in the northern and southern facades was built, fig. 1 . These embrasures were filled with a new generation of autoclaved aerated concrete blocks AEROC Ecoterm (thickness $375 \mathrm{~mm}$ ), with the volume weight $\leq$ $400 \mathrm{~kg} / \mathrm{m}^{3}$, forming joints in the wall with glue mortar. Measurements were regularly taken to determine the wall thermal properties. Certainly, such experiments were performed for the first time and unlike previously performed similar studies of this issue $[2,4,5]$, the wall fragments were studied under circumstances which are specific to individual residential construction in the Baltic republics' region with a humid climate regime. During the experiment, fixed-time conditions are considered in fig. 2, where indoor performance is marked with the symbol $s$, while the symbol $v$ means parameters outside the room [1]. Air humidity and temperature measurements were taken by HOBO loggers. Heat flow and solar radiation data were collected with device ALMEMO-2290-8 and sensors FQA017C, FQA019C and FLA613GS. The uncertainties in all measurements were stated according to devices passports as $0.1 \%$.

Although the AEROC new generation of autoclaved aerated concrete block manufacturers quite seriously follow up its production quality, constructors are interested not only in the material but also in all the walls' heat-engineering indicators. It should be noted that in prior studies $[2,4,5]$ internal and external decoration was not done on the outer walls. However, in the present study, approximately 1 year after the establishment of the wall fragments both internal and external decorations were fulfilled with the company Maxit materials [11]. As a result, the drying process in the walls changed and this is reflected in the following sections. 


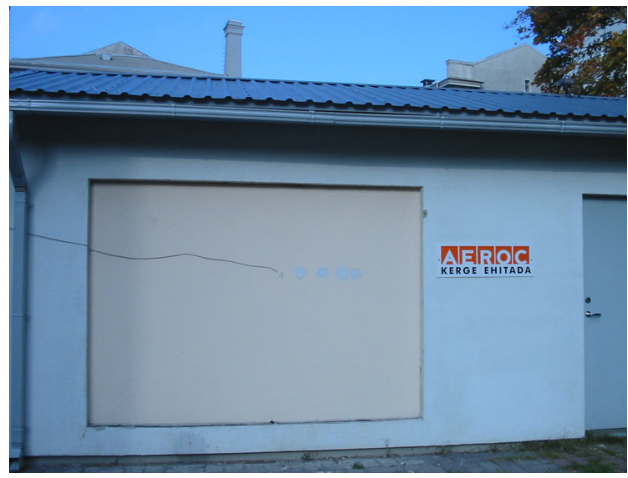

Figure 1: Wall fragment, formed from autoclaved aerated concrete blocks AEROC.
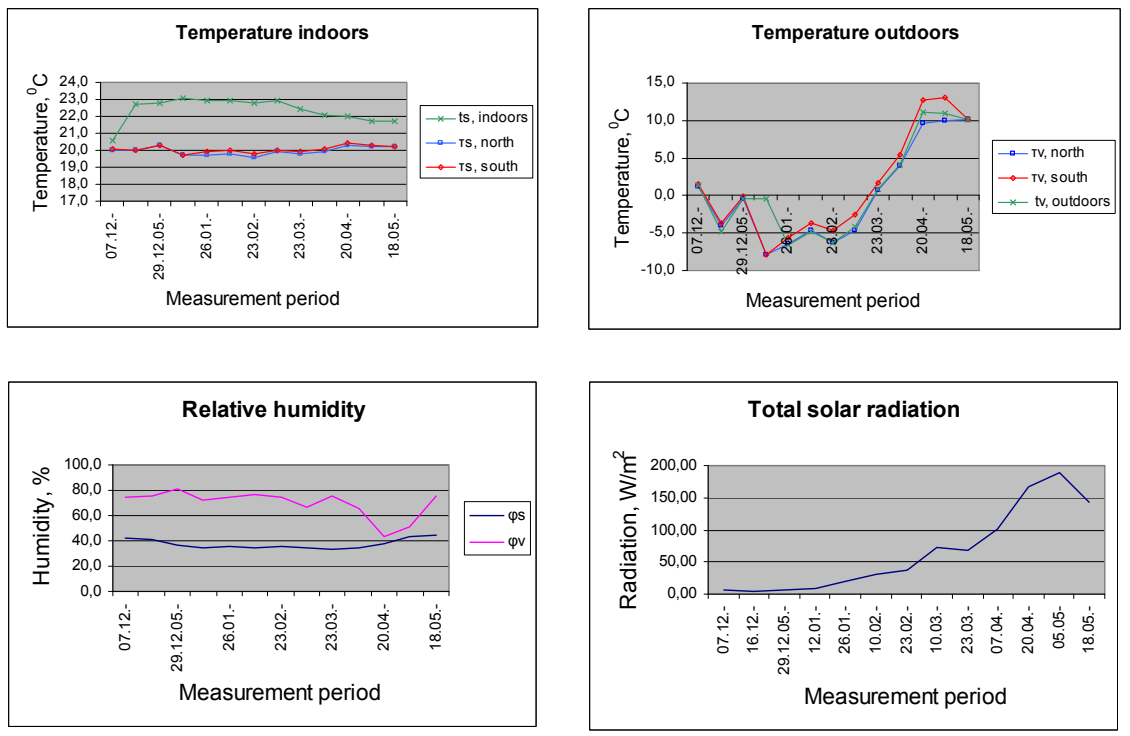

Figure 2: A detailed description of the weather during the experiment.

\section{Weather modeling}

Taking into account the experimentally obtained data [1], a measurement model was created, eqn. (1)-(2) for the outdoors average daily air temperature. Of course, this model is applicable only in the Baltic States climatic zone, and in other regions it should be adjusted to take into account the actual weather data. Experimental (series 2) and modeling (series 1) results obtained are shown in fig. 3. 
282 Advanced Computational Methods and Experiments in Heat Transfer XI

$$
\begin{array}{r}
\tilde{T}(t)=T_{0}+T_{y} \sin \left(2 \pi\left(t+t_{0}\right) /\left(t_{m} t_{h} t_{d} t_{y}\right)\right) \\
T(t)=\tilde{T}(t)+T_{d}\left[\alpha_{d y} \sin \left(2 \pi\left(t+t_{0}\right) /\left(t_{m} t_{h} t_{d} t_{y}\right)\right)+1\right] \\
\sin \left(2 \pi\left(t+t_{d 0}\right) /\left(t_{m} t_{h} t_{d}\right)\right)
\end{array}
$$

where $t$ - time, seconds (starting from 22nd May at 12.00), $t_{0}=23$ days, $\check{T}(t)$ open-air average temperature without taking into account the diurnal temperature variation, $T(t)$ - the average outdoor air temperature subject to the diurnal temperature variation, $t_{d 0}=-4$ hours (the maximum temperature of 14:00, 2 hours after the maximum solar radiation). $T_{0}=6.5^{\circ} \mathrm{C}, T_{y}=12^{\circ} \mathrm{C}, T_{d}=3^{\circ} \mathrm{C}, \alpha_{d y}=0.5, t_{y}$ $=365, t_{d}=24, t_{h}=60, t_{m}=60$.

The average daily outdoor air temperature fluctuations in summer and winter is combined and shown in fig. 4. In Baltic States climatic zone the daily

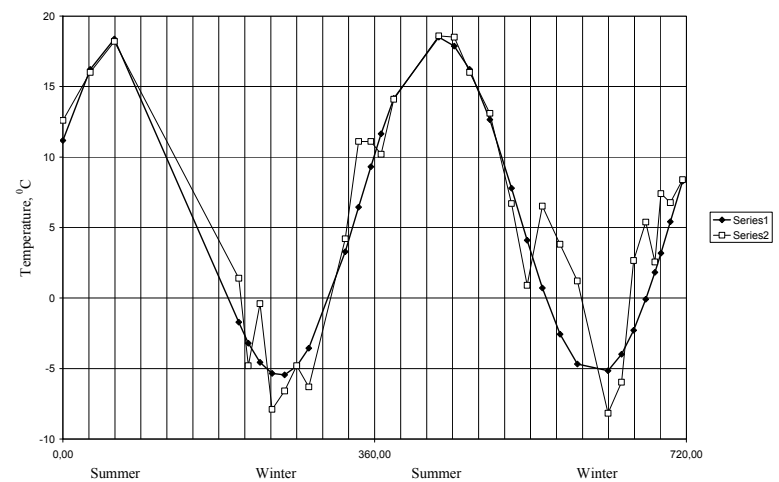

Figure 3: The average daily outdoor air temperature.

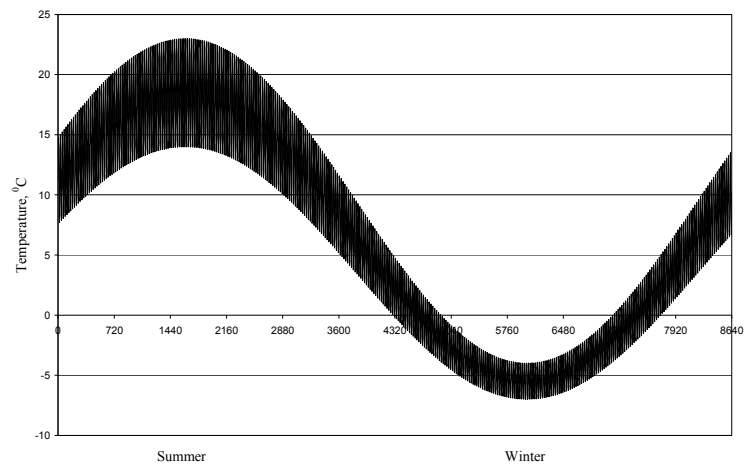

Figure 4: The average daily outdoor air temperature during the simulation. 
temperature in summer is $\pm 4.5^{\circ} \mathrm{C}$, while in winter $\pm 1.5^{\circ} \mathrm{C}$. In this case, it is considered that the indoor temperature does not change significantly and is about $+23^{\circ} \mathrm{C}$.

Similarly as the above mentioned model the solar radiation and outdoor air humidity can be calculated eqn. (3)-(5). The experimental (series 2) and modeling (series 1) results obtained are shown in fig. 5 and fig. 6 .

$$
\begin{aligned}
\widetilde{C}(t) & =C_{0}+C_{y} \sin \left(2 \pi\left(t+t_{C}\right) /\left(t_{m} t_{h} t_{d} t_{y}\right)\right) \\
\widetilde{W}(t) & =W_{0}+W_{y} \sin \left(2 \pi\left(t+t_{W}\right) /\left(t_{m} t_{h} t_{d} t_{y}\right)\right) \\
W(t) & =\widetilde{W}(t)\left[1+\sin \left(2 \pi\left(t+t_{d W}\right) /\left(t_{m} t_{h} t_{d}\right)\right)\right]
\end{aligned}
$$

where $t$ - time (from 22nd of May at 12.00), $t_{c}=273$ days, $t_{w}=61$ days, $\hat{C}(t)-$ outdoor air humidity, $\hat{W}(t)$ - average solar radiation, $W(t)$ - solar radiation, taking

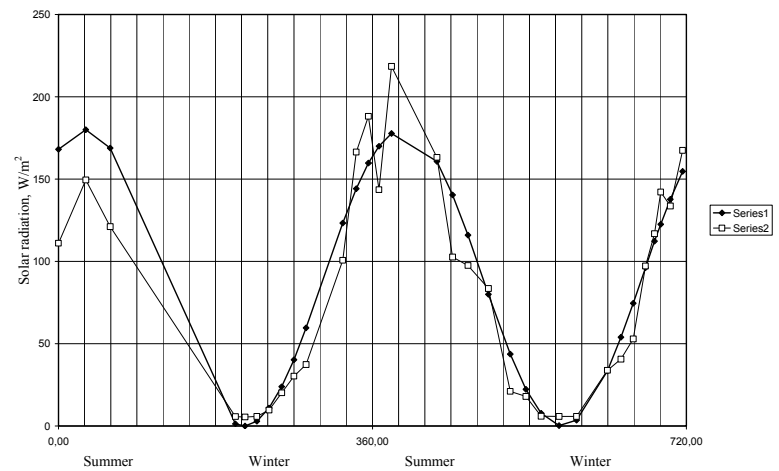

Figure 5: Solar radiation during the simulation.

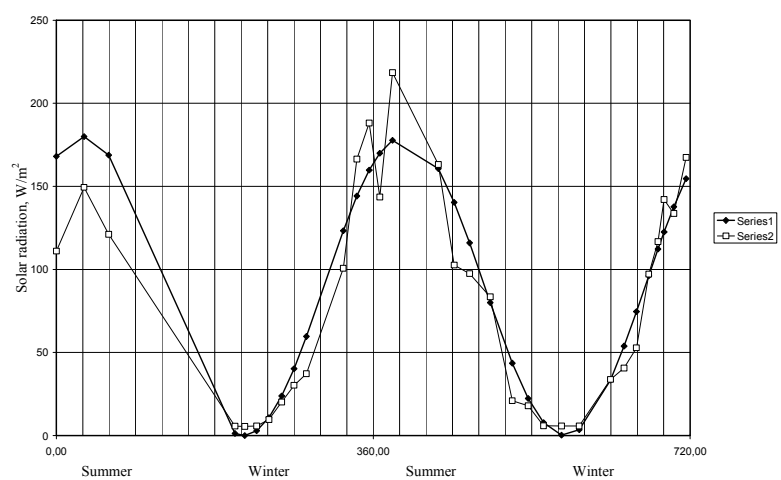

Figure 6: Outdoor air relative humidity during the simulation. 
into account diurnal variations, $C_{0}=70 \%, C_{y}=10 \%, W_{0}=90 \mathrm{~W} / \mathrm{m}^{2}, W_{y}=90$ $\mathrm{W} / \mathrm{m}^{2}$, the phase shift $t_{d w}=-6$ hours (maximum solar radiation is measured every day at 12.00$)$.

In this section analytical calculation formulas are given that can be used to calculate simulating climatic characteristics of the Baltic Sea countries.

\section{Thermal process in the relationship}

Analyzing the experimental results $[1,6,7]$ cross-correlations among various thermal indicators were received. This enables a much better understanding of heat flow and moisture migration processes in autoclaved aerated concrete external walls, as well as providing sound data on the weather impact on these processes.

Fig. 7 demonstrates the phase shift between solar radiation and the outdoor air temperature. This mutual relationship is described by the space part, which is

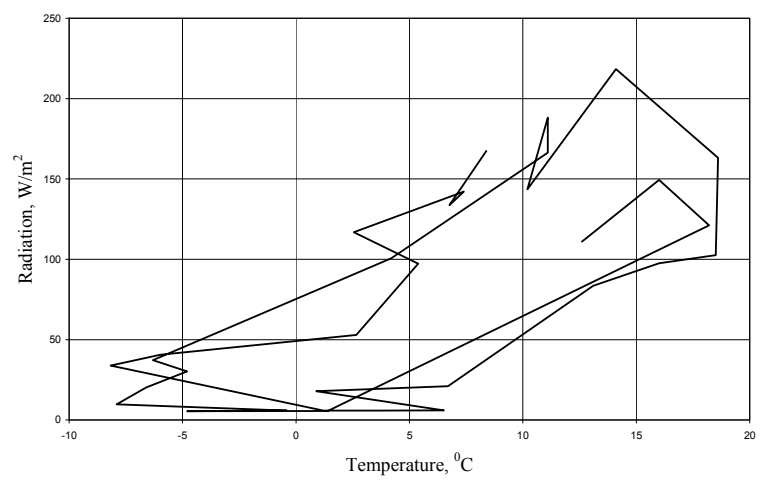

Figure 7: Relationship between solar radiation - outdoor air temperature.

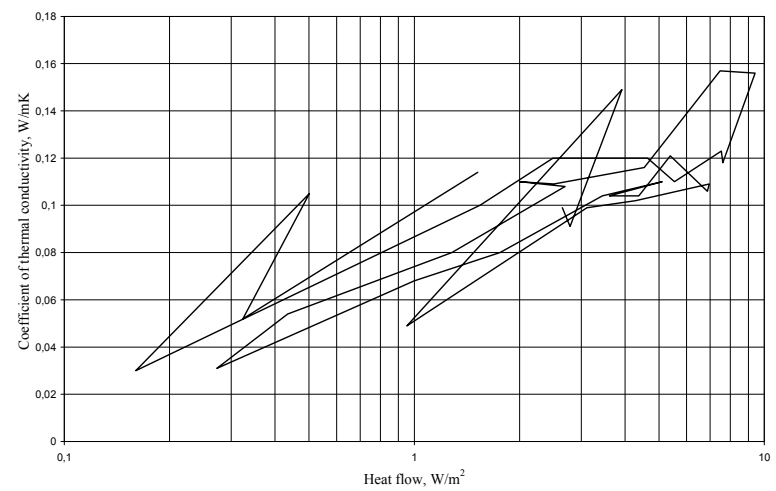

Figure 8: Cross-correlation, coefficient of thermal conductivity - heat flow. 
limited by the hysteresis loop. The mutual relationship, or phase shift, can be seen among other thermal indicators, but is not so obvious.

It is experimentally ascertained $[4,7]$ that the new generation of autoclaved aerated concrete exterior wall thermal conductivity coefficients is not constant in size, but is in some way related to the heat flow through the outer wall (fig. 8), and also related to moisture content in the wall. It could be concluded that the thermal conductivity coefficient is related to the heat flux logarithmic function.

\section{Finishing material effect on the autoclaved aerated concrete wall drying}

To analyze the moisture migration processes in an autoclaved aerated concrete external wall an experiment was held with a boundary construction designed in real conditions (fig.1) to determine the moisture distribution of the wall thickness direction. Wall drying process measurements [1] were started after about 4 months from the completion of the exterior wall construction. Samples were taken from the wall, which humidity met the European standard EN 1353 methodic [8]. The samples were taken from the middle part of the wall with a step (wall thickness) of $50 \mathrm{~mm}$. Under the requirements of the standard the samples were weighed immediately after their removal (wet basis) and, immediately upon removal from the drying chamber, where they reached constant weight. The samples were taken eight times from both the south and the north wall fragments. The results are collected and displayed in fig. 9. Taking into account the technology of sample taking, the uncertainties in this measurement were evaluated as $4 \%$. The vertical axis shows autoclaved aerated concrete sample moisture percentage from the weight, while the horizontal axis shows the dates when the samples were taken. The symbols $\mathrm{S} 1, \ldots \mathrm{S} 8$ represent a concrete outer wall with the size of the samples with the wall thickness of $50 \mathrm{~mm}$. The symbol S1 is assigned for internal walls round, while the symbol S8 - wall outer layer.
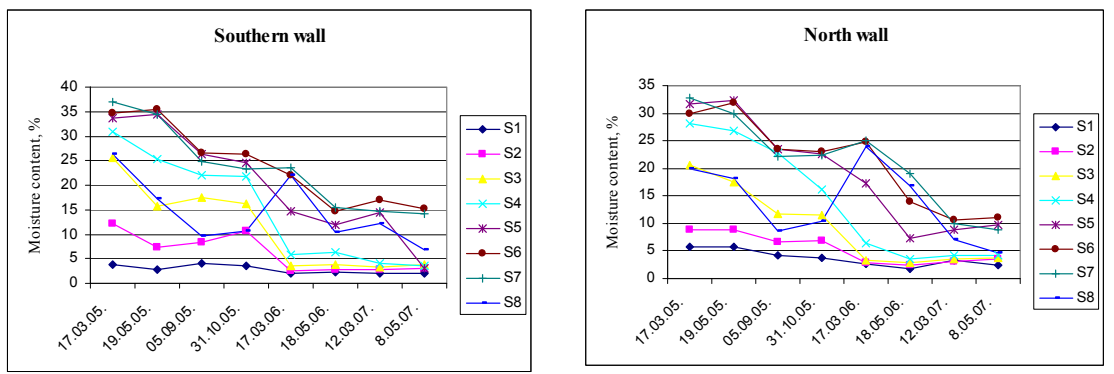

Figure 9: Drying dynamics of the individual layers of the autoclaved aerated concrete wall.

As can be seen from the experimentally obtained curves, the moisture distribution of the wall thickness is uneven and varies several times. This is 
easily explained because water evaporation is faster exactly from the external surface of the autoclaved aerated concrete blocks. In fact, it can be concluded that the process of wall drying in winter time is dominated by the direction from inside to outside. While, during the summer period, when the outside air temperature is higher, the moisture movement takes place in the opposite direction, but mostly it can be concluded that the autoclaved aerated concrete wall dries towards the outside. This is also confirmed by the experimentally obtained drying curves (fig. 10), which clearly show that the amount of moisture inside the wall is significantly lower than that in the wall outside.
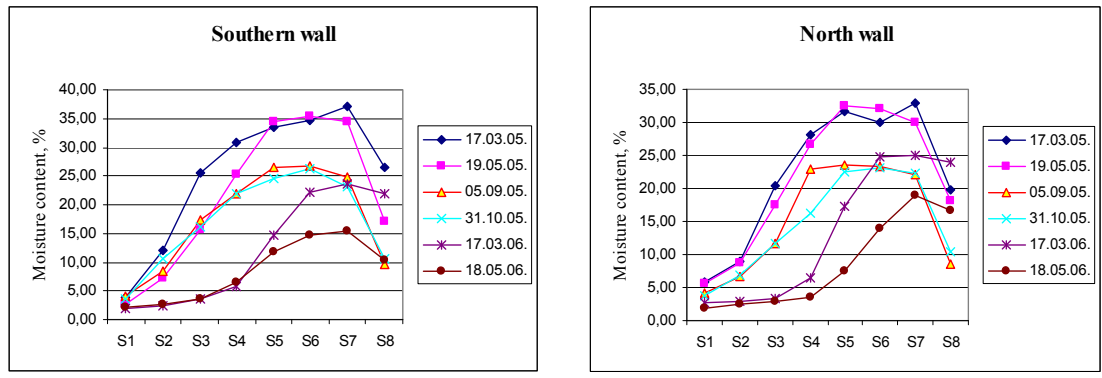

Figure 10: Moisture distribution in autoclaved aerated concrete external wall thickness.

Drying processes in the new generation of autoclaved aerated concrete outer wall thickness can be described in eqn. (6) and (7):

$$
\begin{gathered}
Y(t)=22.57 \exp (-0.0017 t) \\
Y(t)=24.02-0.0456 t+3 \times 10^{-5} t^{2}
\end{gathered}
$$

where $Y(t)$ - moisture by weight, $\%, t$ - time, day.

Experimentally and analytically by eqn. (6) and (7) obtained data for the new generation of autoclaved aerated concrete exterior walls average humidity is shown in fig. 11.
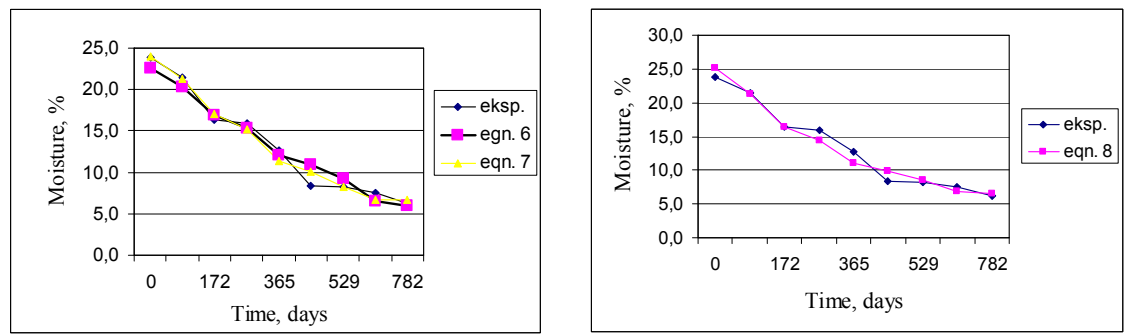

Figure 11: The new generation of autoclaved aerated concrete outer wall with Maxit finishing average moisture changes over time. 
Taking into account that in the known period outside walls average humidity will stabilize it would be more correct instead of eqn. (6) and (7) to use the following formula:

$$
Y(t)=5.0+20.13 \exp (-0.0033 t)
$$

Fig. 11 demonstrates that eqn. (8) may be equally effective using both the new generation of autoclaved aerated concrete exterior walls at the beginning of drying, as well as in the long-term.

It is also explained by the fact that the outer walls of the internal part is in a positive temperature zone that is close to the indoor air temperature. While the outer walls are exposed to the negative impact of the outdoor air temperature in winter, which significantly affects the moisture diffusion Speed, it can be concluded that the outer wall moisture diffusion rate decreases according to the rule of exponential functions and therefore have a high moisture area directly in the outer part of the exterior walls, but not in the middle part, as is observed at equilibrium moisture entry.

Another factor that directly affected moisture distribution and diffusion speed is that approximately 1 year after the establishment of the wall fragments both internal and external decoration were made with the materials Maxit Serpo [11]. To determine directly the impact of the external finishes on the moisture migration in autoclaved aerated concrete external walls, an additional experiment with 15 pairs of samples with different finishes was completed fig.12. One of the prepared sample pairs was without decoration, while the other sample pairs were with various combinations of the finishes from the company SAKRET materials [12] - KAM, BG, CLR, GAM, PG, LH, silicate earth, silicate paint, SBR2 and MRP2.

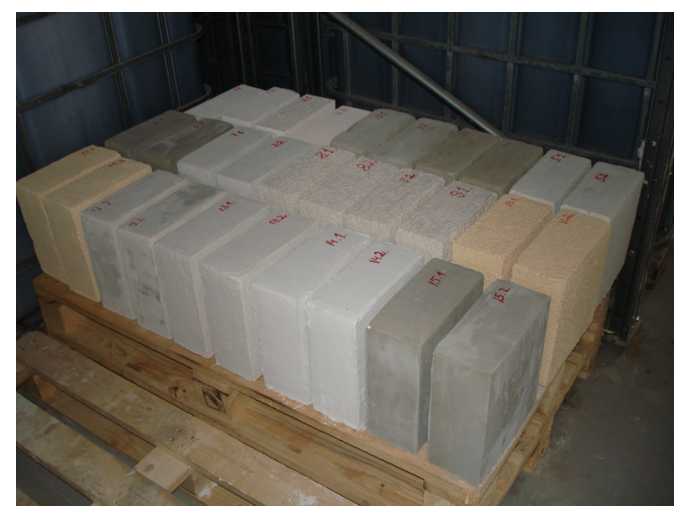

Figure 12: Autoclaved aerated concrete blocks samples with different finishes.

Prepared samples were weighed before finishing deposition and after finishing deposition and dried for four months under natural conditions. During the drying period, the samples were stored in a warehouse, where there were no 
abrupt climate changes, and the samples were periodically weighed every fourth day. The sample weight without finishing was $3.4 \mathrm{~kg}$, but after finishing it rose to $4.2 \mathrm{~kg}$. During the experiment, a sample lost on average $0.64 \mathrm{~kg}$ from the original weight and actually reached equilibrium moisture in each new generation of autoclaved aerated concrete sample. That was possible in such a short time because the sample thickness of $100 \mathrm{~mm}$ was significantly lower than the experimental block outer wall thickness $375 \mathrm{~mm}$. Thanks largely to this thickness difference, it was possible to achieve equilibrium moisture indicators almost eight times faster compared with the experimental outer wall drying speed, fig. 11.

Autoclaved aerated concrete block samples with different external finishes drying dynamics are shown in fig.13. The difference between the weight of the block of the experiment at the beginning and at the end of the experiment (moisture weight) was compared and is presented in a logarithmic scale. It is seen that the model drying process can be reasonably well described by the graphs of the exponential functions. Basing on the experimental results, it can be concluded that the finish material effect on the new generation of autoclaved aerated concrete outer walls drying process is significant because the difference between the sample without finishing (marked line) and with different Sakret finishing combination drying time is approximately 2.5 times.

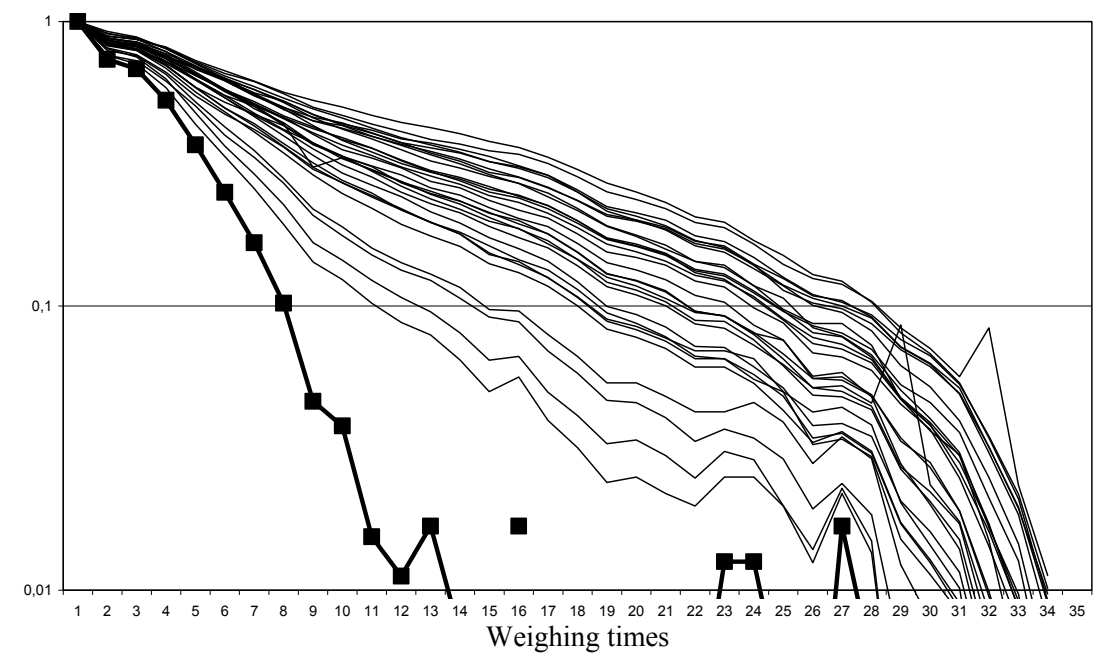

Figure 13: Drying dynamics of the autoclaved aerated concrete block samples with different finishes between the weighing times.

The analysis of the different finishes material combination effects on moisture migration in the experiment shows that it is not so efficient because changes in the average size are within a 10 per cent limit. Of course, these conclusions are based solely on the Sakret finishing materials used in the experiment and their sizes, which means that the real impact of construction finishing materials on the 
drying process of a wall can be completely different. This is visible in fig. 10 which represents moisture distribution in the outer wall thickness, which is calculated exactly for this reason, as essential moisture distribution at the external (on average 10\%) and internal (on average 3\%) construction surface. Although in this case, the moisture distribution at the construction external and internal surface varies about 3 times, it is mostly the result of finishing material impact.

As it is well known, the moisture and heat flow processes [9] in autoclaved aerated concrete containment structures are quite complex and are seen only as the mutual relationship and interaction of various factors.

From the experimental results, it can be concluded that the external wall finishes are preferably fulfilled after the first heating season with a finishing material which water vapor permeability factor $-\mu$ is equivalent to $\mu$ value of the new generation of autoclaved aerated concrete material. According to experimental data [10] the $\mu$ value for the new generation of autoclaved aerated concrete is 4 to 6, for Maxit Serpo finishing is 21.6, for Sakret MRP finishing is 9.5 , but for lime-cement plastering it is 6 .

\section{Conclusion}

1. A calculation model of the climatic parameters for the Baltic countries climatic zone has been made. It can be used for simulating the performance of climatic parameters in the Baltic Sea countries, while in other regions it should be adjusted to take into account the real climatic data.

2. The coefficient of thermal conductivity is related to the heat flux logarithmic function. Largely, these changes are associated with different moisture migration processes in the new generation of autoclaved aerated concrete wall thickness.

3. Moisture distribution in the new generation of autoclaved aerated concrete external wall is not uniform. The inside surface of an external wall dries sooner than the exterior outer wall since it is under more favorable conditions, which reports directly to the changing weather conditions and finishing materials.

4. Moisture distribution and moisture migration in outer wall thickness is also influenced by external decoration material. The new generation of autoclaved aerated concrete external wall finishing should have a similar water vapor permeability factor $-\mu$ with the $\mu$ value of wall material. The external finishes are recommended to be completed after the first heating season, when the autoclaved aerated concrete outer wall has given away most of the moisture associated in closed pores.

\section{Acknowledgement}

This work has been supported by the European Social Fund within the project "Support for the implementation of doctoral studies at Riga Technical University". 


\section{References}

[1] Ю. Тамм \& Э. Йыгиоя. Итоговый отчет. Определение теплотехнических свойств и влажностного режима стен из блоков AEROC EcoTerm. Tallinn, pp. 1-34, 2006.

[2] Сажнев Н. П. и др. Производство ячеистобетонных изделий: теория и практика. Стринко: Минск, рр. 152-168, 1999.

[3] Фокин К.Ф., Табунщиков Ю.А. \& Гагарин В.Г. Строительная теплотехника ограждающих частей зданий. Изд. 5-е. Авок-Пресс: Москва, pp. 182-203, 2006.

[4] Стерлягов А.Н. Совместный тепло- и влагоперенос в ограждающих конструкциях зданий из газобетона: автореф. дис. канд. техн. наук. Новосибирск, рр. 59-70, 2007.

[5] Ухова Т. А. и др. О корректировке равновесной влажности и теплопроводности ячеистого бетона. Строительные материалы. Июнь 2006.

[6] Вилнитис. М. Я. и др. Исследование процессов высыхания и теплового потока стен из газобетона AEROC. Строительные материалы и изделия выпуск 24, 2007.

[7] Vilnītis M. \& Noviks J. Research of heat transfer processes in walls made from „new generation” autoclaved aerated concrete. Publications: RTU zinātniskie raksti, Arhitektūra un būvzinātne, Rīga, pp. 96-103, 2007.

[8] European standard EN 1353. Determination of moisture content of autoclaved aerated concrete.

[9] Latvian Construction Standard LBN 002-01 Thermotechnics of Building Envelopes.

[10] AEROC, http://www.aeroc.lv/index.php?page=634\&lang=lat

[11] Maxit, http://eerus.maxit-cms.com/3601

[12] Sakret, http://www.sakret.lv/public/25288.html 